\section{Hydrophysical Properties, Moisture Retention, and Drainage Profiles of Wood and Traditional Components for Greenhouse Substrates}

\author{
Jeb S. Fields ${ }^{1}$, William C. Fonteno², and Brian E. Jackson ${ }^{3,5}$ \\ North Carolina State University, Department of Horticultural Science, 114 \\ Kilgore Hall, Campus Box 7609, Raleigh, NC 27695
}

Joshua L. Heitman ${ }^{4}$

North Carolina State University, Department of Soil Science, 3410 Williams Hall, Campus Box 7619, Raleigh, NC 27695

James S. Owen, Jr. ${ }^{3}$

Virginia Polytechnic Institute \& State University, Department of Horticulture, Hamptons Road Agricultural Research Station, 1444 Diamond Springs Road, Virginia Beach, VA 23455

Additional index words. peat, perlite, pine tree substrate, soil matric tension, Van Genuchten model

\begin{abstract}
Pine tree substrates (PTSs) may provide growers with sustainable substrate component options. Improved processing of PTS components has provided new materials with little scientific evaluation or understanding of their hydrophysical behavior and properties. Moisture retention characteristics were developed for two PTSs and four traditional greenhouse components: sphagnum peat, coconut coir, perlite, pine bark, shredded-pine-wood (SPW), and pine-wood-chips (PWC). Mixtures of peat containing $10 \%, 20 \%, 30 \%, 40 \%$, and $50 \%$ of perlite, SPW, or PWC were also characterized. Hydrophysical properties were measured, allowing for comparison of the PTS components to the more traditional substrate components (peat, coir, perlite, and pine bark). The SPW was constructed to retain water similarly to peat and pine bark, whereas the PWC was made to increase drainage like perlite. Shredded pine wood had higher total porosity and more easily available water than did PWC components. Total porosities of SPW and PWC were similar to pine bark and coir; air space and drainage were higher than peat and coir because of the lower percentage of fine particles in the PTS components. The two PTS components had a greater influence on water drainage and retention dynamics than did perlite when amended with peat as an aggregate. Water release patterns of SPW or PWC components at low tensions were lower than peat and greater than pine bark; drainage was similar to perlite at higher tensions. Equilibrium capacity variable models predicted similar physical properties (and trends) across multiple container sizes for peat mixes amended with perlite, SPW, or PWC. The impact of PWC on drainage and aeration was similar to perlite in all containers, but these effects were greater in smaller containers.
\end{abstract}

Identifying a substrate's ability to hold and release water is critical to improving the efficiency of water use in greenhouse crops. Moisture retention curves (MRCs) in soilless substrates were first described by Bunt (1961) and are obtained in a similar fashion to mineral

Received for publication 4 Mar. 2014. Accepted for publication 1 May 2014.

This article is a portion of a thesis submitted by Jeb S. Fields as required to fulfill degree requirements. Mention of proprietary products or private companies is included for the reader's convenience and does not imply any endorsement.

${ }^{1}$ Former Graduate Research Assistant.

${ }^{2}$ Professor.

${ }^{3}$ Assistant Professor.

${ }^{4}$ Associate Professor.

${ }^{5}$ To whom reprint requests should be addressed; e-mail Brian_Jackson@ncsu.edu. will hold and desorb water at low tensions. Bilderback and Fonteno (1987) were then able to more accurately describe $\mathrm{CC}$ as being a function of container geometry.

Fonteno (1989) described how MRCs could be used to determine available and unavailable water for a substrate in a container. Substrate water is not held at the same tensions throughout the entire range of its availability. Instead, each tension setting causes a different volume of water to be desorbed from the substrate (Karlovich and Fonteno, 1986). Moreover, individual substrates tend to desorb water dissimilar to other substrates. A five-parameter nonlinear model was introduced, which is able to more accurately predict relationships between volumetric water content $(\Theta)$ and water potential $(\mathrm{Y})$ than previous models (Van Genuchten and Nielsen, 1985). The five-parameter Van Genuchten model (Van Genuchten and Nielsen, 1985) was then adapted for horticultural substrates by Milks et al. (1989a) and is as follows:

$$
\Theta=\Theta_{\mathrm{r}}+\left(\Theta_{\mathrm{s}}-\Theta_{\mathrm{r}}\right) /\left[1+(\alpha \times \mathrm{h})^{\mathrm{n}}\right]^{\mathrm{m}}
$$

where $\Theta$ is volumetric water content, $\Theta_{\mathrm{s}}$ is the volumetric water content at saturation $(0 \mathrm{kPa}), \Theta_{\mathrm{r}}$ is the residual water content $(-30 \mathrm{kPa}), \mathrm{h}$ is the height of the column or moisture tension, $\alpha$ is the inverse of the "air entry value," and $n$ and $m$ are curve-fitting parameters. Values of $\Theta_{s}$ and $\Theta_{r}$ from Van Genuchten's model can be used in an equilibrium capacity variable (ECV) model to determine basic physical properties [total porosity (TP), AS, and CC] of a substrate for a specific size and shaped container (Bilderback and Fonteno, 1987; Milks et al., 1989b). Container size has been proven to significantly alter substrate properties and in turn plant growth and development (Bish et al., 1997; Milks et al., 1989c; Owen and Altland, 2008). Substrates placed in larger containers do not provide the same physical properties when used in smaller volume containers such as flats or plugs (Argo, 1998; Milks et al., 1989b, 1989c). The ECV models can be used to estimate the hydrophysical properties in several substrate/container combinations simultaneously.

The first objective of this research was to define the MRCs of two PTSs and to compare them with traditional components of perlite and peat. The second objective was to determine MRCs for mixtures of peat and either perlite, SPW, or PWCs. Identifying similarities and differences in hydraulic properties between the two PTS components and among traditional components is an important step in furthering the usability of PTS as greenhouse substrate components. The third objective of this research was to use the ECV models derived from the MRCs to compare the PTS components with perlite in substrate mixes in different container sizes.

\section{Materials and Methods}

Substrate preparation. Two components were manufactured from pine wood to have 
different physical characteristics. Pine wood chips were created as follows: loblolly pine trees (Pinus taeda L.) were harvested on 9 Dec. 2011 and processed through a DR Chipper (18 HP DR Power Equipment, Model 356447; Vergennes, VT) on 3 Jan. 2012 to produce coarse wood chips that were then hammermilled through a $6.35-\mathrm{mm}$ screen (Meadows Mills, North Wilkesboro, NC) on 5 Jan. 2012. Shredded pine wood was created with separate loblolly pine trees harvested on 12 Dec. 2011 and shredded in a Wood Hog shredder (Morbark, Winn, MI) on 9 Jan. 2012. The coarse shredded wood was then hammermilled as previously described for PWC on 10 Jan. 2012. On visual inspection, the two wood components exhibited substantially different geometries with the PWC being nonfibrous "blockular" with smooth edges and the SPW being more linear and fibrous in nature.

Peat moss (Premier Hort Tech, Canada) was screened $(6.35 \mathrm{~mm})$ and hydrated to a moisture content (MC) of $50 \%$ by weight. Perlite (horticultural grade; Carolina Perlite Company, Gold Hill, NC), PWC, and SPW were each blended with peat at $10 \%, 20 \%$, $30 \%, 40 \%$, and $50 \%$, by volume totaling 15 mixes. In addition, $100 \%$ components of peat, perlite, PWC, SPW, aged pine bark (PB), and coconut coir pith (Densu Coir, Canada) were also tested to attain characteristics of other traditionally used greenhouse substrate components. This resulted in 21 substrates used in this study (15 mixtures + six components).

Physical properties and particle size distribution. Total porosity, AS, CC, and bulk density (BD) were determined for each of the 21 substrates using the North Carolina State University (NCSU) Porometer (Fonteno and Harden, 2010). Particle size distribution tests were then conducted on 100 -g samples previously dried to $105{ }^{\circ} \mathrm{C}$ for $48 \mathrm{~h}$ using sieves (Fisher Scientific Co., Pittsburgh, PA) of 6.3, $2.0,0.71,0.5,0.25$, and $0.106 \mathrm{~mm}$, shaken in a Ro-Tap ${ }^{\circledR}$ Shaker (Model B; WS Tyler Industrial Group, Mentor, $\mathrm{OH}$ ), for $5 \mathrm{~min}$.

Moisture retention curves. Moisture retention curves were obtained using procedures in the North Carolina State University Horticulture Substrates Laboratory Manual (Fonteno and Harden, 2010). Each sample was placed in a $7.5 \mathrm{~cm}$ tall $\times 7.5-\mathrm{cm}$ i.d. aluminum core and placed in Volumetric Pressure Plate Extractors (VPPE; Soilmoisture Corp., Santa Barbara, CA) fitted with $50-\mathrm{kPa}$ ceramic plates (Soilmoisture Corp.). The experiment was conducted in a controlled-temperature chamber (NCSU Horticultural Substrates Laboratory) held at $22{ }^{\circ} \mathrm{C}$.

Four samples of each substrate were packed to the same BD as those samples used in the NCSU Porometers for easy comparison. Samples were saturated with tap water in a stepwise fashion and allowed to equilibrate for $48 \mathrm{~h}$ before drainage. Samples were then allowed to freely drain for an additional $48 \mathrm{~h}$ with water effluent volumes recorded. Pressures of 2.0, 4.0, 5.0, 7.5, 10, 20, and $30 \mathrm{kPa}$ were then applied. Each pressure was applied for $24 \mathrm{~h}$, and drainage from each substrate sample was recorded. Samples were exposed to pressures of $30 \mathrm{kPa}$, equilibrated, and then removed from the VPPEs and weighed. The samples were then dried at $105^{\circ} \mathrm{C}$ for $48 \mathrm{~h}$ and then reweighed and $\Theta$ was calculated.

Plotting the MRCs and modeling. Once all desired suctions had a corresponding $\Theta$, a scatterplot was made to show the relationship between the two properties. Values for $0 \mathrm{kPa}$ (saturation) and $-0.38 \mathrm{kPa}$ (initial drainage) were taken from TP and CC values derived from the porometer data. Values for EAW, and WBC, which categorize a substrate's water-holding ability, were then calculated, as shown by de Boodt and Verdonck (1972), from points on the curve. Using the NLIN procedure of SAS (Version 9.2; SAS Institute, Cary, NC) predicted means for each value for each substrate were plotted, which allowed them to be fitted with the fiveparameter Van Genuchten model for horticultural substrates (Milks et al., 1989a).

Equilibrium capacity variable models. Using values obtained by modeling the MRC curves with Van Genuchten's model, ECV models were performed to determine simulated physical properties of the substrate in different sized and shaped containers (Milks et al., 1989b). These models use $\Theta_{\mathrm{s}}$ and $\Theta_{r}$, and the three curve fitting parameters $(\alpha, n$, and $m)$ as well as individual container geometries and volumes to describe the values in $\mathrm{CC}$ and $\mathrm{AS}$ as the container changed. In measuring containers for the models, no two pots from different manufacturers were exactly the same. Therefore, the containers chosen for these models were composites of several containers in production. The dimensions and volumes of each were as follows: $3.9-\mathrm{L}$ pot $=7.7-\mathrm{cm}$ bottom radius, $8.7-\mathrm{cm}$ lip radius, $9.2-\mathrm{cm}$ top radius, $17.8 \mathrm{~cm} \cdot \mathrm{h}^{-1}$, $3.623-\mathrm{L}$ volume; $15-\mathrm{cm}$ pot $=5.3-\mathrm{cm}$ bottom radius, $6.55-\mathrm{cm}$ lip radius, $7.50-\mathrm{cm}$ top radius, $14.4 \mathrm{~cm} \cdot \mathrm{h}^{-1}, 1.368-\mathrm{L}$ volume; $10-\mathrm{cm}$ pot $=$ $3.6-\mathrm{cm}$ bottom radius, $4.75-\mathrm{cm}$ lip radius, $5.05-\mathrm{cm}$ top radius, $8.8 \mathrm{~cm} \cdot \mathrm{h}^{-1}, 0.413-\mathrm{L}$ volume; bedding plant flat $(48)$ cell $=1.84 \mathrm{~cm}$, $2.78-\mathrm{cm}$ top radius, $5.2 \mathrm{~cm} \cdot \mathrm{h}^{-1}, 0.088-\mathrm{L}$ volume; plug cell $(273)=0.51-\mathrm{cm}$ bottom radius, $1.07-\mathrm{cm}$ top radius, $2.5 \mathrm{~cm} \cdot \mathrm{h}^{-1}, 4.5$-cc volume.

Statistics were performed for the hydrologic properties in Table 1 and Table 2 using SAS with Tukey's honestly significant difference with $\alpha=0.05$ to observe similarities and differences between different substrates for each property. Regression analysis was also done for each property to determine the effects of amendment ratio with peat. Table 3 was produced from mathematically derived modeling algorithms, which required means of repetitions to produce curve-fitting parameters for use in the models. To validate the model, means of moisture retention data were compared with points of corresponding $\Theta$ and to model predictions using the $7.6-\mathrm{cm}$ aluminum cylinder as the container.

\section{Results and Discussion}

Physical properties. Perlite had the lowest $\mathrm{TP}$ of all substrates in the experiment, $\approx 10 \%$ and $12 \%$ volume less than the next lowest substrates, PB and PWC, respectively (Table 1). Shredded pine wood TP was volumetrically 5\% higher than PWC. Shredded pine wood and perlite had the same $\mathrm{CC}$, whereas

Table 1. Physical and hydrologic properties of six traditional and alternative greenhouse substrate components. ${ }^{2}$

\begin{tabular}{|c|c|c|c|c|c|c|c|c|c|}
\hline Component & $\mathrm{TP}^{\mathrm{y}}$ & $\mathrm{CC}^{\mathrm{x}}$ & $\mathrm{AS}^{\mathrm{w}}$ & $\mathrm{Db}^{\mathrm{v}}$ & EAW $^{\mathrm{u}}$ & $\mathrm{WBC}^{\mathrm{t}}$ & RW10s & RW30 ${ }^{\mathrm{r}}$ & $\mathrm{PFP}^{\mathrm{q}}$ \\
\hline Peat & $91.0 \mathrm{a}^{\mathrm{p}}$ & $80.1 \mathrm{a}$ & $10.7 \mathrm{c}$ & $0.12 \mathrm{c}$ & $17.7 \mathrm{a}$ & $5.9 \mathrm{a}$ & $36.4 \mathrm{a}$ & $26.8 \mathrm{c}$ & $51.6 \mathrm{~b}$ \\
\hline $\mathrm{SPW}^{\circ}$ & $84.1 \mathrm{~b}$ & $52.8 \mathrm{c}$ & $31.3 \mathrm{~b}$ & $0.18 \mathrm{ab}$ & $13.9 \mathrm{a}$ & $2.1 \mathrm{c}$ & $33.8 \mathrm{~b}$ & $33.9 \mathrm{a}$ & $19.7 \mathrm{~d}$ \\
\hline $\mathrm{PWC}^{\mathrm{n}}$ & $78.8 \mathrm{c}$ & $41.6 \mathrm{~d}$ & $37.2 \mathrm{a}$ & $0.18 \mathrm{ab}$ & $5.6 \mathrm{c}$ & $0.5 \mathrm{~d}$ & $33.9 \mathrm{~b}$ & $33.7 \mathrm{a}$ & $6.8 \mathrm{e}$ \\
\hline Pine bark & $76.0 \mathrm{c}$ & $42.5 \mathrm{~d}$ & $33.5 \mathrm{ab}$ & $0.21 \mathrm{a}$ & $3.2 \mathrm{c}$ & $0.2 \mathrm{~d}$ & $22.6 \mathrm{e}$ & $22.2 \mathrm{~d}$ & $21.5 \mathrm{c}$ \\
\hline
\end{tabular}

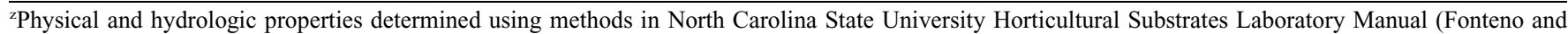
Harden, 2010).

${ }^{\mathrm{y}} \mathrm{TP}=$ total porosity is the total percentage of pore volume in a substrate.

${ }^{\mathrm{x}} \mathrm{CC}=$ container capacity is equal to the maximum water content a substrate can achieve after gravitational drainage has taken place.

${ }^{\mathrm{w}} \mathrm{AS}=$ air space which is the total percentage of pore space not filled with water at $\mathrm{CC}(\mathrm{TP}=\mathrm{CC}+\mathrm{AS})$.

${ }^{\mathrm{v}} \mathrm{Db}=$ bulk density is the weight of the oven dry material/total volume of sample.

"EAW $=$ easily available water is water lost between $-1 \mathrm{kPa}$ and $-5 \mathrm{kPa}$.

${ }^{\mathrm{t}} \mathrm{WBC}=$ water-buffering capacity water lost between $-5 \mathrm{kPa}$ and $-10 \mathrm{kPa}$.

${ }^{\mathrm{s}} \mathrm{RW} 10=$ residual water (volumetric water content) of substrate component sample at $-10 \mathrm{kPa}$.

${ }^{\mathrm{r}} \mathrm{RW} 30=$ residual water (volumetric water content) of sample at $-30 \mathrm{kPa}$.

qPFP = percent of fine-sized particles (greater than $0.71 \mathrm{~mm}$ ). Determination of particle size was done on $100 \%$ components only.

${ }^{\mathrm{p} S t a t i s t i c s ~ w e r e ~ d e t e r m i n e d ~ d o w n ~ c o l u m n ~ f o r ~ i n d i v i d u a l ~ p r o p e r t i e s ~ u s i n g ~ T u k e y ' s ~ h o n e s t l y ~ s i g n i f i c a n t ~ d i f f e r e n c e ~ w i t h ~} \alpha=0.05, \mathrm{n}=5$.

${ }^{\circ} \mathrm{SPW}=$ loblolly pine (Pinus taeda) trees processed through a shredder and then hammermilled through a 6.35 -mm screen.

${ }^{\mathrm{n}} \mathrm{PWC}=$ loblolly pine trees processed through a wood chipper and then hammermilled through a 6.35 -mm screen. 
Table 2. Physical and hydrologic properties of peat amended with $50 \%, 40 \%, 30 \%, 20 \%, 10 \%$, and $0 \%$ perlite, shredded pine wood, or pine wood chips. ${ }^{2}$

\begin{tabular}{|c|c|c|c|c|c|c|c|c|}
\hline & $\mathrm{TP}^{\mathrm{y}}$ & $\mathrm{CC}^{\mathrm{x}}$ & $\mathrm{AS}^{\mathrm{w}}$ & $\mathrm{Db}^{\mathrm{v}}$ & $\mathrm{EAW}^{\mathrm{u}}$ & $\mathrm{WBC}^{\mathrm{t}}$ & $\mathrm{RW} 10^{\mathrm{s}}$ & RW30 \\
\hline Mix ratio & \multicolumn{8}{|c|}{ Peat:perlite } \\
\hline $50: 50$ & $85.6 \mathrm{e}^{\mathrm{q}}$ & $68.3 \mathrm{~g}$ & $17.3 \mathrm{ab}$ & 0.12 ef & $11.2 \mathrm{~d}$ & $5.5 \mathrm{ab}$ & $27.8 \mathrm{~g}$ & $18.8 \mathrm{~h}$ \\
\hline $60: 40$ & $85.7 \mathrm{e}$ & 72.5 defg & $13.2 \mathrm{bcd}$ & $0.13 \mathrm{def}$ & $11.9 \mathrm{~cd}$ & $5.8 \mathrm{ab}$ & $28.4 \mathrm{~g}$ & $19.6 \mathrm{gh}$ \\
\hline $70: 30$ & 87.1 abcde & 74.8 def & $12.3 \mathrm{bcd}$ & $0.13 \mathrm{de}$ & $14.3 \mathrm{abcd}$ & $5.2 \mathrm{bc}$ & $29.2 \mathrm{~g}$ & $20.6 \mathrm{fgh}$ \\
\hline $80: 20$ & 87.4 bcde & 76.2 cde & $11.1 \mathrm{~d}$ & $0.12 \mathrm{ef}$ & $12.9 \mathrm{bcd}$ & $5.0 \mathrm{bc}$ & $28.6 \mathrm{~g}$ & $20.3 \mathrm{fgh}$ \\
\hline $90: 10$ & 88.3 bcde & $77.0 \mathrm{bcd}$ & $11.3 \mathrm{~d}$ & $0.12 \mathrm{ef}$ & $16.4 \mathrm{ab}$ & $5.1 \mathrm{bc}$ & $29.7 \mathrm{~g}$ & $22.2 \mathrm{efg}$ \\
\hline 100:0 & $91.0 \mathrm{abc}$ & $80.1 \mathrm{abc}$ & $10.7 \mathrm{~d}$ & $0.12 \mathrm{f}$ & $17.7 \mathrm{a}$ & $5.9 \mathrm{ab}$ & $36.4 \mathrm{~cd}$ & $26.8 \mathrm{~d}$ \\
\hline \multirow[t]{2}{*}{ Significance $^{\mathrm{p}}$} & L*** & L*** & $\mathrm{L}^{* * *}$ & NS & $\mathrm{L}^{* * *}$ & NS & $\mathrm{L}^{* *}$ & $\mathrm{~L} * * *$ \\
\hline & $\mathrm{Q}^{* *}$ & $\mathrm{Q}^{* * *}$ & $\mathrm{Q}^{* * *}$ & NS & $\mathrm{Q}^{* * *}$ & NS & NS & $\mathrm{Q}^{* *}$ \\
\hline Mix ratio & \multicolumn{8}{|c|}{ Peat:shredded pine wood } \\
\hline $50: 50$ & 89.4 abcde & $70.8 \mathrm{fg}$ & $18.7 \mathrm{ab}$ & $0.14 \mathrm{~cd}$ & $11.3 \mathrm{~d}$ & $3.1 \mathrm{e}$ & $32.3 \mathrm{f}$ & $27.4 \mathrm{~cd}$ \\
\hline $60: 40$ & $91.3 \mathrm{ab}$ & $72.4 \mathrm{efg}$ & $19.3 \mathrm{a}$ & $0.14 \mathrm{bc}$ & $10.2 \mathrm{~d}$ & $3.4 \mathrm{de}$ & 34.9 cde & $30.0 \mathrm{bc}$ \\
\hline $70: 30$ & $90.5 \mathrm{abcd}$ & 76.2 cde & $14.4 \mathrm{abcd}$ & $0.13 \mathrm{de}$ & $12.9 \mathrm{bcd}$ & $4.3 \mathrm{~cd}$ & $33.7 \mathrm{def}$ & $27.1 \mathrm{~d}$ \\
\hline $80: 20$ & $92.5 \mathrm{a}$ & $80.6 \mathrm{abc}$ & $11.9 \mathrm{~cd}$ & $0.12 \mathrm{ef}$ & $17.7 \mathrm{a}$ & $5.4 \mathrm{~b}$ & $29.1 \mathrm{~g}$ & $22.7 \mathrm{ef}$ \\
\hline $90: 10$ & $92.1 \mathrm{a}$ & $80.9 \mathrm{ab}$ & $11.1 \mathrm{~d}$ & 0.12 ef & $17.8 \mathrm{a}$ & $6.5 \mathrm{a}$ & $32.5 \mathrm{ef}$ & $23.8 \mathrm{e}$ \\
\hline $100: 0$ & $91.0 \mathrm{abc}$ & $80.1 \mathrm{abc}$ & $10.7 \mathrm{~d}$ & $0.12 \mathrm{f}$ & $17.7 \mathrm{a}$ & $5.9 \mathrm{ab}$ & $36.4 \mathrm{~cd}$ & $26.8 \mathrm{~d}$ \\
\hline \multirow[t]{2}{*}{ Significance } & NS & $\mathrm{L} * * *$ & $\mathrm{~L}^{* * *}$ & $\mathrm{~L} * * *$ & $\mathrm{~L} * * *$ & $\mathrm{~L} * * *$ & NS & NS \\
\hline & NS & $\mathrm{Q}^{* * *}$ & $\mathrm{Q}^{* * *}$ & $\mathrm{Q}^{* * *}$ & $\mathrm{Q}^{* * *}$ & $\mathrm{Q}^{* * *}$ & $\mathrm{Q}^{*}$ & NS \\
\hline Mix ratio & \multicolumn{8}{|c|}{ Peat:pine wood chips } \\
\hline $50: 50$ & $86.1 \mathrm{de}$ & $69.1 \mathrm{~g}$ & $17.0 \mathrm{abc}$ & $0.16 \mathrm{a}$ & $10.8 \mathrm{~d}$ & $2.8 \mathrm{e}$ & $38.8 \mathrm{ab}$ & $36.6 \mathrm{a}$ \\
\hline $60: 40$ & 89.5 abcde & $71.0 \mathrm{fg}$ & $18.5 \mathrm{ab}$ & $0.16 \mathrm{a}$ & $11.3 \mathrm{~d}$ & $2.7 \mathrm{e}$ & $39.6 \mathrm{a}$ & $36.2 \mathrm{a}$ \\
\hline $70: 30$ & 89.1 abcde & $73.8 \mathrm{def}$ & $15.3 \mathrm{abcd}$ & $0.15 \mathrm{ab}$ & $14.0 \mathrm{abcd}$ & $3.7 \mathrm{de}$ & $37.1 \mathrm{bc}$ & $32.0 \mathrm{~b}$ \\
\hline $80: 20$ & $90.9 \mathrm{abc}$ & $80.3 \mathrm{abc}$ & $10.6 \mathrm{~d}$ & $0.13 \mathrm{~cd}$ & $15.8 \mathrm{abc}$ & $4.9 \mathrm{bc}$ & $34.2 \mathrm{def}$ & $27.8 \mathrm{~cd}$ \\
\hline $90: 10$ & $91.8 \mathrm{ab}$ & $81.3 \mathrm{a}$ & $10.6 \mathrm{~d}$ & $0.13 \mathrm{def}$ & $17.9 \mathrm{a}$ & $5.5 \mathrm{ab}$ & $34.3 \mathrm{def}$ & $26.6 \mathrm{~d}$ \\
\hline $100: 0$ & $91.0 \mathrm{abc}$ & $80.1 \mathrm{abc}$ & $10.7 \mathrm{~d}$ & $0.12 \mathrm{fg}$ & $17.7 \mathrm{a}$ & $5.9 \mathrm{ab}$ & $36.4 \mathrm{~cd}$ & $26.8 \mathrm{~d}$ \\
\hline \multirow[t]{2}{*}{ Significance } & $\mathrm{L} * * *$ & $\mathrm{~L} * * *$ & $\mathrm{~L} * * *$ & $\mathrm{~L} * * *$ & $\mathrm{~L}^{* * *}$ & $\mathrm{~L} * * *$ & NS & $\mathrm{L} * * *$ \\
\hline & $\mathrm{Q}^{* * *}$ & $\mathrm{Q} * * *$ & $\mathrm{Q}^{* * *}$ & $\mathrm{Q}^{* * *}$ & $\mathrm{Q}^{* * *}$ & $\mathrm{Q}^{* * *}$ & NS & $\mathrm{Q}^{*}$ \\
\hline
\end{tabular}

${ }^{2}$ Physical and hydrologic properties determined using methods in North Carolina State University Horticultural Substrates Laboratory Manual (Fonteno and Harden, 2010).

${ }^{\mathrm{y}} \mathrm{TP}=$ total porosity is the total percentage of pore volume in a substrate.

${ }^{\times} \mathrm{CC}=$ container capacity is equal to the maximum water content a substrate can achieve after gravitational drainage.

${ }^{\mathrm{w}} \mathrm{AS}=$ air space, which is the total percentage of pore space not filled with water at $\mathrm{CC}(\mathrm{TP}=\mathrm{CC}+\mathrm{AS})$.

${ }^{\mathrm{v}} \mathrm{Db}=$ bulk density is the weight of the oven dry material/total volume of sample.

"EAW = easily available water is water lost between $-1 \mathrm{kPa}$ and $-5 \mathrm{kPa}$.

${ }^{\mathrm{t}} \mathrm{WBC}=$ water-buffering capacity water lost between $-5 \mathrm{kPa}$ and $-10 \mathrm{kPa}$.

${ }^{\mathrm{s}} \mathrm{RW} 10=$ volume percentage of water remaining in the sample at $-10 \mathrm{kPa}$.

${ }^{\mathrm{r}} \mathrm{RW} 30=$ volume percentage of water remaining in the sample at $-30 \mathrm{kPa}$.

${ }^{\natural}$ Statistics were determined within a column across all components and ratios for individual properties using Tukey's honestly significant difference with $\alpha=0.05$.

${ }^{\mathrm{P}}$ Significance of the rate of amendment on the property with $\mathrm{L}$ being linear and Q being quadratic and $\mathrm{NS}=$ non-significant, ${ }^{* * *} P \leq 0.001,{ }^{* *} P \leq 0.01,{ }^{*} P \leq 0.05$.

PWC was $10 \%$ lower than both. This is likely the result of a difference in surface area and pore sizes between the two PTS components. The SPW being more fibrous would be hypothesized to have a greater surface area and micropore volume than the PWC with larger particles and smoother edges. Perlite had 33\% fine particles (PFP) followed by PB (21.5\%) and SPW (19.7\%) with PWC being the lowest (6.8\%; Table 1). More "fines" can result in correspondingly higher surface area and a higher percentage of smaller sized pores in perlite vs. SPW vs. PWC (Table 1; Hillel, 2008). Hillel (2008) also described how water is held with the highest tension on the surfaces of particles followed by the smallest diameter pores. Therefore, more water was held in the perlite and SPW than in PWC.

Air space in perlite was approximately one-third that of SPW and PWC but the same as $100 \%$ peat. The unexpected similarity in AS between peat and perlite is most likely explained by the perlite source used in this experiment being one that contained finer particles (more dust) as indicated by the $33 \%$ fines reported in Table 1. Finer-sized particles are able to fill in smaller voids, which allow them to pack more closely within themselves and create fewer macropores
(Hillel, 2008). Pine wood chips and PB had the same AS, alluding to both materials being viable for increasing drainage of a substrate mixes (being used as an aggregate).

Pine wood chips and PB had a lower EAW content than peat, coir, SPW, and perlite, which is likely the result of a higher ratio of macropores, which are formed as a result of a lower PFP in the PWC (Table 1), and a high percentage of "extra-large" (greater than $6.3 \mathrm{~mm}$ ) sized particles in PB (not presented). The high number of macropores would also contribute to PWC having nearly a 50:50 split between CC and AS

The $100 \%$ peat and coir's WBC was significantly higher than that of any other component, which means plants will be able to pull water between -5 and $-10 \mathrm{kPa}$ easier from these materials (Table 1). There was a similar downward slope for peat, coir, and perlite between -5 and $-10 \mathrm{kPa}$, whereas both the PWC and SPW have a more gradual slope throughout the range of tensions (Fig. 1). This may infer that at this tension range, peat and perlite are quite similar in percentage of water that is released.

Total porosity for all ratios of perlite and PWC mixes tended to decrease with increases in percentage of amendments to the peat (Table 2), which was expected because these amendments had higher $\mathrm{BD}$ and are much less porous than peat. The TP for the different ratios of SPW did not change with increasing amendment percent; however, the ratio of CC to AS making up TP did. The TP ranges in the SPW and PWC mixes were similar. Container capacity followed similar patterns for mixes with all three amendments, an increase in CC with a decrease in amendment, and $9 \%$ to $11 \%$ difference between the highest and lowest amendment rate with increasing AS resulting from an increasing percentage of amendment. The range of AS in all substrate mixtures was $10 \%$ to $19 \%$ by volume.

The EAW also increased with a decrease in percentage of all amendments with peat and mixes with high peat ratios having the highest EAW (Table 2). There were few differences among components in EAW when comparing similar mix ratios. The only instance where there was a difference was in 80:20 peat:SPW, which did have a slightly higher EAW than the 80:20 peat:perlite (Table 2). There was no difference between ratios of peat:perlite in WBC, which was equal to that of $100 \%$ peat. The SPW and PWC mixes lose less moisture in this pressure range than do the perlite mixes; however, both the SPW and PWC mixes show 
Table 3. Mathematically derived physical properties of peat amended with $10 \%, 20 \%, 30 \%, 40 \%$, and $50 \%$ perlite, shredded pine wood, and pine wood chips, derived from modeling equilibrium capacity variable values. ${ }^{2}$

\begin{tabular}{|c|c|c|c|c|c|c|c|c|c|c|}
\hline \multirow{2}{*}{$\begin{array}{l}\text { Amendment } \\
\text { percentage }\end{array}$} & \multicolumn{10}{|c|}{ Container size } \\
\hline & \multicolumn{2}{|c|}{ Plug tray ${ }^{y}$} & \multicolumn{2}{|c|}{ BP flat ${ }^{x}$} & \multicolumn{2}{|c|}{$10 \mathrm{~cm}^{\mathrm{w}}$} & \multicolumn{2}{|c|}{$15 \mathrm{~cm}^{\mathrm{v}}$} & \multicolumn{2}{|c|}{$3.9 \mathrm{~L}^{\mathrm{u}}$} \\
\hline & \multicolumn{10}{|c|}{ Perlite mixes } \\
\hline $20 \%$ & 86.7 & 0.6 & 79.4 & 7.9 & 72.4 & 14.9 & 62.3 & 25.1 & 57.3 & 30.1 \\
\hline $30 \%$ & 85.3 & 2.8 & 77.8 & 10.3 & 72.3 & 15.8 & 63.6 & 24.5 & 59.0 & 29.1 \\
\hline $40 \%$ & 83.5 & 2.2 & 75.8 & 9.9 & 70.0 & 15.7 & 61.2 & 24.5 & 56.7 & 29.0 \\
\hline \multirow[t]{2}{*}{$50 \%$} & 80.4 & 6.6 & 72.0 & 15.0 & 66.9 & 20.1 & 59.3 & 27.6 & 55.3 & 31.7 \\
\hline & \multicolumn{10}{|c|}{ Shredded pine wood mixes } \\
\hline $10 \%$ & 90.1 & 4.7 & 83.0 & 11.8 & 78.3 & 16.5 & 70.6 & 24.2 & 66.2 & 28.6 \\
\hline $20 \%$ & 90.7 & 1.8 & 83.6 & 9.0 & 77.4 & 15.1 & 67.5 & 25.0 & 62.2 & 30.4 \\
\hline $30 \%$ & 88.4 & 2.2 & 80.2 & 10.3 & 74.0 & 16.5 & 65.0 & 25.6 & 60.4 & 30.1 \\
\hline $40 \%$ & 89.0 & 2.7 & 78.4 & 13.3 & 71.5 & 20.2 & 62.4 & 29.3 & 58.1 & 33.6 \\
\hline \multirow[t]{2}{*}{$50 \%$} & 86.6 & 2.8 & 76.4 & 13.0 & 69.6 & 19.8 & 60.4 & 29.0 & 56.1 & 33.4 \\
\hline & \multicolumn{10}{|c|}{ Pine wood chips mixes } \\
\hline $50 \%$ & 81.1 & 5.0 & 73.4 & 12.7 & 68.9 & 17.2 & 62.3 & 23.8 & 59.0 & 27.1 \\
\hline
\end{tabular}

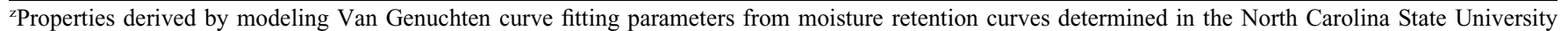
Horticultural Substrates Laboratory. Data were produced from mathematically derived modeling algorithms, which required means of repetitions to produce curve-fitting parameters for use in the models.

${ }^{\mathrm{y}}$ Individual cell from a plug tray containing 273 individual cells $(4.5 \mathrm{cc})$.

${ }^{\mathrm{x}}$ Individual cell from a bedding plant flat tray containing 48 individual cells $(88.5 \mathrm{cc})$.

${ }^{\mathrm{w}}$ Container $10 \mathrm{~cm}$ tall commonly used in greenhouse crop production $(413 \mathrm{cc})$.

${ }^{\mathrm{v} C}$ Container $15 \mathrm{~cm}$ tall commonly used in greenhouse crop production $(1368 \mathrm{cc})$.

"Container with volume of $3.9 \mathrm{~L}$ used in greenhouse/nursery crop production.

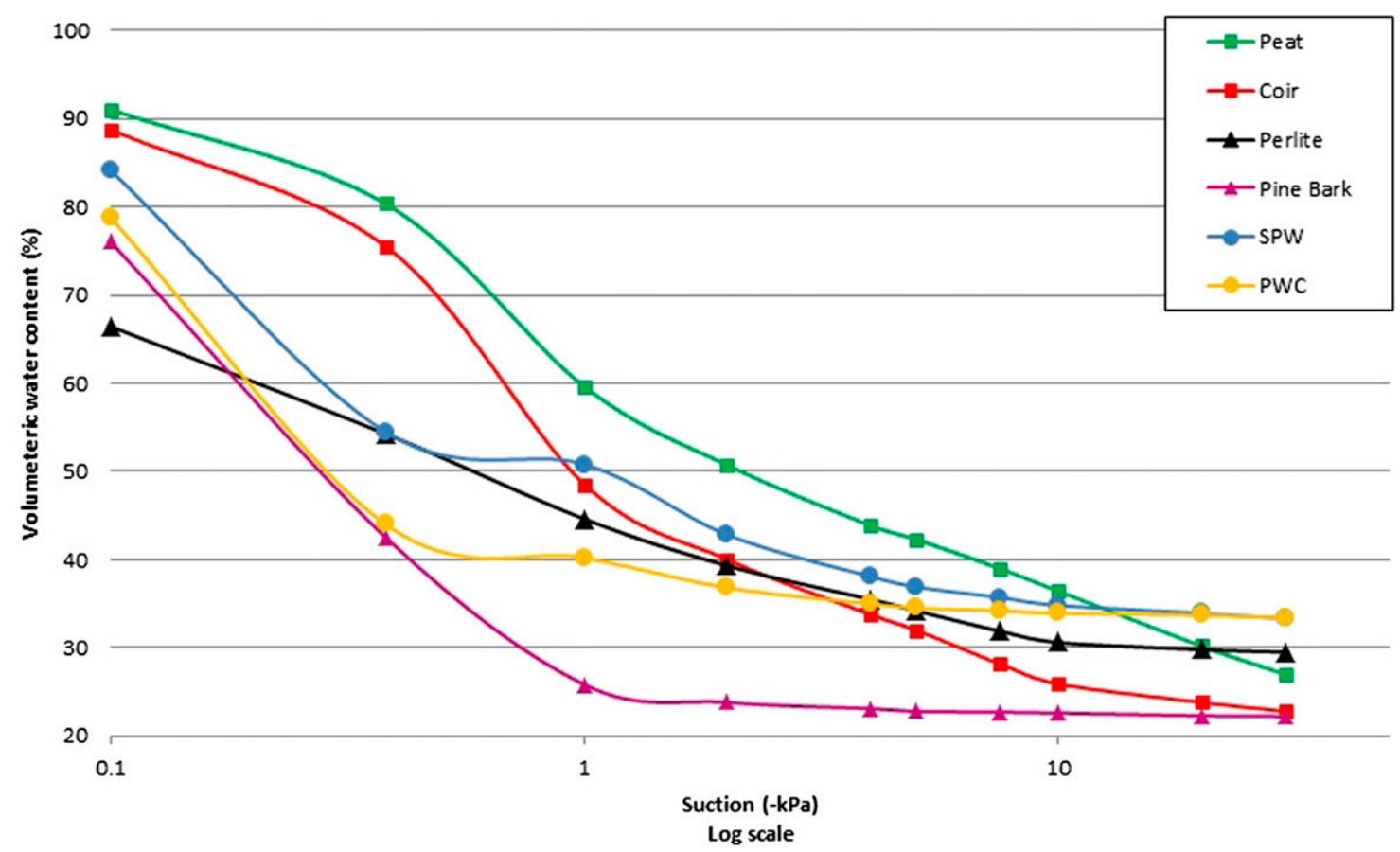

Fig. 1. Moisture retention curves of peat, coconut coir, perlite, aged pine bark, shredded pine wood (SPW; Pinus taeda), and pine wood chip (PWC) substrate components.

a significant increase in WBC with decreasing amendment percentage, whereas the perlite mixes did not. This explains the differences in the slopes of the SPW and PWC vs. the peat and perlite (Fig. 1). The SPW does not release much water after $-4.0 \mathrm{kPa}$, and $\mathrm{PWC}$ does not release much water after $-2.0 \mathrm{kPa}$, whereas perlite continues to release water steadily until $-10 \mathrm{kPa}$; peat showed a decrease in moisture at every tension applied (Fig. 1). The $\Theta$ at -10 $\mathrm{kPa}$, known from this point forward as residual water (RW10; Table 1), allows for comparisons of the substrates at the higher tensions. There is a slight linear relationship for RW10 of peat:perlite mixes and a slight quadratic relationship for the peat:SPW mixes with no significant relationship existing between the peat:PWC mixes. This shows that although there are differences in $\mathrm{MC}$ at $-10 \mathrm{kPa}$ between the treatments, there is a common pattern to moisture release for these materials. 
The RW for the PWC mixes was significantly higher than the SPW mixes, which in turn was significantly higher than the perlite mixes. This was a result of a loss of connectivity in the PWC at lower tensions as a result of a lower PFP. The lower the PFP, the less hydraulic conductivity a material has (Argo, 1998). This lower hydraulic conductivity causes the water column to break, thus not allowing water to drain easily. This is also the reasoning for the leveling off of the MRCs for both SPW and PWC (Fig. 1). Also shown in Table 1 is the $\Theta$ at $-30 \mathrm{kPa}$ (RW30), which provides evidence as to what happens between -10 and $-30 \mathrm{kPa}$. The PWC mixes did not lose much moisture from -10 to $-30 \mathrm{kPa}$, whereas the perlite mixes did.

Moisture retention curves. The MRCs for the component materials show well-defined differences among all six materials (Fig. 1). The peat and coir followed similar drainage patterns. At low tensions, the SPW and PWC components held water volumes in between coir/peat and PB but showed drainage patterns similar to the perlite at higher tensions. Of the two PTS materials, the PWC drained more rapidly than the SPW at moderate tensions, but both materials had similar $\Theta$ at $-30 \mathrm{kPa}$. The PB had the steepest drainage slope with the majority of the water being released by $-1 \mathrm{kPa}$.

Figure 2 contains data of peat blended with perlite, PWC, and SPW in ratios of $10 \%$ to $50 \%$ by volume. At $10 \%$, perlite shows more drainage $(0.38 \mathrm{kPa})$ than either the PWC or SPW. However, the drainage values for $20 \%$ to $50 \%$ blends were the same for all three materials. On the other end of the scale, as percent volumes increase, the amount of water retained from 10 to $30 \mathrm{kPa}$ increases with PWC and SPW additions but remained the same for perlite. Indeed, the residual water values in Table 1 (R10 and R30) are higher for the two wood components than for perlite. These data provide evidence that perlite and the wood components are quite similar in drainage profiles with the wood materials holding more residual water. This occurred despite the fact that perlite had a larger percent fine particles than SPW or PWC (PFP; Table 1).

Equilibrium capacity variable models. Regardless of container size and shape, the percentage of solids and therefore total pore space remained unchanged (Table 3). This was expected, because total porosity is unaffected by container size as long as BD is constant (Milks et al., 1989b). There was a change in CC and AS with changing container size. From the 273-cell plug tray to the 15 -cm pots, there was a 10 -fold difference in AS. Container capacity decreased $\approx 20 \%$. The greater drainage in the taller containers was a result of the increased gravitational forces drawing more water out of the smaller void spaces in taller containers, which was demonstrated by Spomer (1974). There was also increased hydraulic head in the taller containers, creating more positive pressure on the water in the pore space, causing more drainage. These trends were found among
Peat $+10 \%$

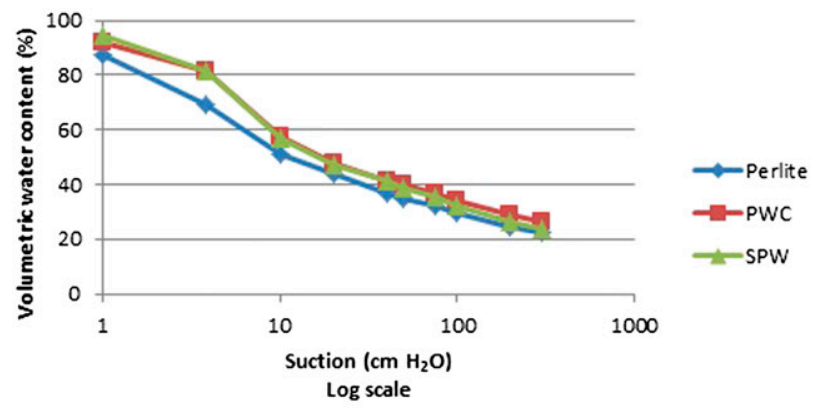

Peat $+20 \%$

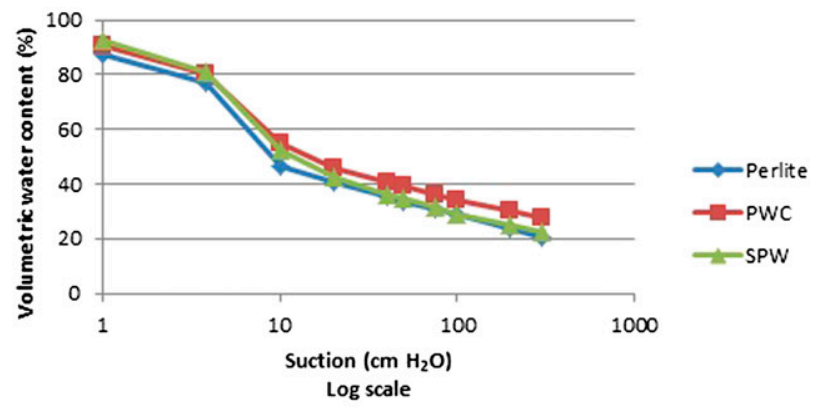

Peat $+30 \%$
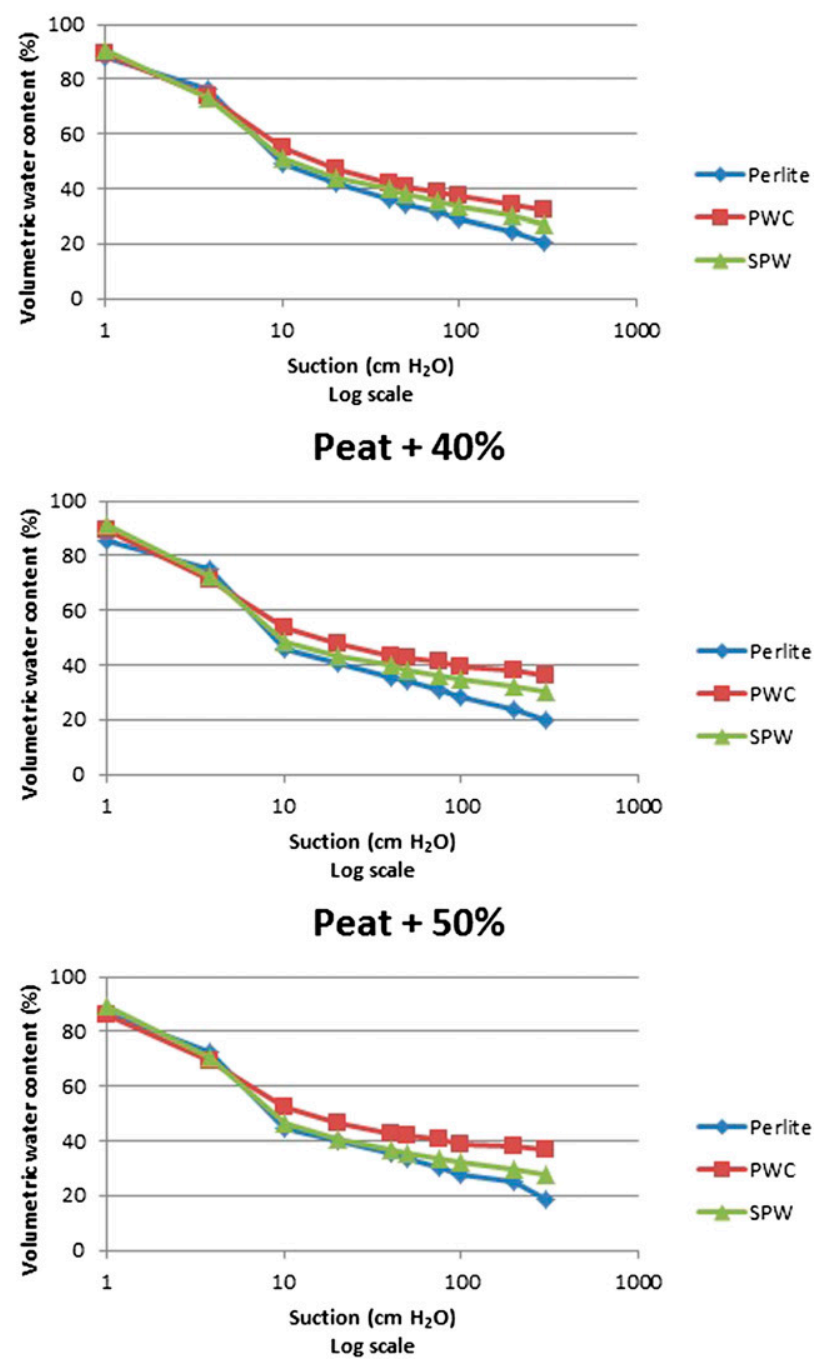

Fig. 2. Moisture release curves of peat amended with $10 \%, 20 \%, 30 \%, 40 \%$, and $50 \%$ perlite, pine wood chips (PWC), or shredded pine wood (SPW; Pinus taeda). 
substrates of equal ratios and containers. As the container size is decreased, the differences in $\mathrm{AS}$ and $\mathrm{CC}$ among ratios and aggregate type are diminished. For example, looking specifically at the 70:30 peat:amendment ratio (a common substrate ratio for professional grower substrates) in the smallest containers (plug trays), we see a larger (4.4\%) AS in the PWC substrate, which is nearly double the values reported in the perlite $(2.8 \%)$ and the SPW substrate $(2.2 \%)$. As container size increased, the differences in AS among the three substrates at the 70:30 amendment ratio were diminished until there was relatively no difference among any of the substrates (Table 3).

The presumed lowered hydraulic conductivity of the PTS components also may allow water to be stored in a substrate at higher tensions than substrates with perlite as an amendment. Caron et al. (1998) showed that xylem stress is first observable when substrate water potential reaches $-10 \mathrm{kPa}$. Kiehl et al. (1992) showed water stress in chrysanthemums starts at $-16 \mathrm{kPa}$. At the $70: 30$ peat:amendment ratio, there was a significant difference between the RW of the three different substrates at $-10 \mathrm{kPa}$. Perlite, SPW, and PWC substrates at $30 \%$ amendment yielded $29.2 \%, 33.7 \%$, and $37.1 \%$ of pore space filled with water at $-10 \mathrm{kPa}$, respectively. The RW of a $30 \%$ PWC mix at $-30 \mathrm{kPa}$ was $32 \%$ higher than the $30 \%$ perlite substrate at three times the tension (Table 3). Karlovich and Fonteno (1986) also described the relationship between $\Theta$ and tension being different for every substrate; the $\mathrm{MC}$ was more crucial in producing higher quality plants. Puustjarvi and Robertson (1975) reported that the majority of greenhouse crops are irrigated at tensions between 0 and $-10 \mathrm{kPa}$, which would render this unimportant; however, once a plant leaves the greenhouse and is moved to the marketplace and ultimately to the consumer, there is a high likelihood that tensions beyond -10 $\mathrm{kPa}$ will be regularly achieved.

Irrigation regimes can be determined by monitoring soil or substrate moisture tension, and therefore the development of MRCs can be a useful and important tool for greenhouse and nursery managers (Obreza et al., 1997). The similarities in physical properties between PWC and PB are also very extensive, alluding to possible use of PWCs as a replacement or extender for PB.
The ECV models provided a good representation of the differences in component physical properties in different stages of crop production. There are some slight differences between the amendments in smaller sized containers; however, neither amendment used has been classified for use in plug containers. The representations of the larger sized containers, where these amendments are more likely to be used, show that there is not much difference in physical properties regardless of which amendment is used.

\section{Conclusions}

The two PTS components had a greater influence on substrate hydrology than perlite when incorporated into a peat mixture. Percentages of perlite in a peat:perlite mixture did not create any difference in substrate physical properties when used between $10 \%$ and $40 \%$ of a mixture. Pine tree substrates tended to affect the dynamics of a substrate with increasing influence coming from increasing percentages of wood.

The two PTS components used in this experiment were manufactured to exact specifications. Altering one or more of the manufacturing processes could lead to a change in hydrophysical properties as well as drainage profiles of these materials. Jackson et al. (2010) demonstrated different ways to produce PTS and the differences in physical properties rendered with different manufacturing processes for PTS. Therefore, any further research may show differences in physical properties of PTS components if not manufactured using the same process.

\section{Literature Cited}

Argo, W.R. 1998. Root medium physical properties. HortTechnology 8:481-485.

Bilderback, T.E. and W.C. Fonteno. 1987. Effects of container geometry and media physical properties on air and water volumes in containers. J. Environ. Hort. 5:180-182.

Bish, E.B., D.J. Cantliffe, and C.K. Chandler. 1997. Container volume and media particle size alters growth of strawberry transplants. Proc. Fla. State Hort. Soc. 110:258-261.

Bunt, A.C. 1961. Some physical properties of potplant composts and their effects on growth. Plant Soil 13:322-332.

Caron, J., H.L. Xu, P.Y. Bernier, I. Duchesne, and P. Tardif. 1998. Water availability in three artificial substrates during Prunus $\times$ cisternae growth: Variable threshold values. J. Amer. Soc. Hort. Sci. 123:931-936.

de Boodt, M. and O. Verdonck. 1972. The physical properties of the substrates in horticulture. Acta Hort. 26:37-44.

Fonteno, W.C. 1989. An approach to modeling air and water status of horticultural substrates. Acta Hort. 238:67-74.

Fonteno, W.C. and C.T. Harden. 2010. North Carolina State University Horticultural substrates lab manual. North Carolina State University, Raleigh, NC.

Hillel, D. 2008. Environmental soil physics. Elsevier Academic Press, San Diego, CA.

Jackson, B.E., R.D. Wright, and M.C. Barnes 2010. Methods of constructing a pine tree substrate from various wood particle sizes, organic amendments, and sand, for desired physical properties and plant growth. HortScience 45:103-112.

Karlovich, P. T. and W.C. Fonteno. 1986. Effect of soil moisture tension and soil water content on the growth of chrysanthemum in 3 container media. J. Amer. Soc. Hort. Sci. 111:191-195.

Kiehl, P. A., J. H. Lieth, and D.W. Burge. 1992. Growth response of Chyrsanthemum to various container medium moisture tension levels. J. Amer. Soc. Hort. Sci. 117:224-229.

Milks, R.R., W.C. Fonteno, and R.A. Larson. 1989a. Hydrology of horticultural substrates: I. Characteristics of horticultural container media. J. Amer. Soc. Hort. Sci. 114:48-52.

Milks, R.R., W.C. Fonteno, and R.A. Larson. 1989b. Hydrology of horticultural substrates: II. Predicting physical properties of media in containers. J. Amer. Soc. Hort. Sci. 114:5356.

Milks, R.R., W.C. Fonteno, and R.A. Larson. 1989c. Hydrology of horticultural substrates: III. Predicting air and water content in limitedvolume plug cells. J. Amer. Soc. Hort. Sci. 114:57-61.

Obreza, T.A., D. J. Pitts, L.R. Parsons, T.A. Wheaton, and K.T. Morgan. 1997. Soil waterholding characteristics affects citrus irrigation scheduling strategy. Proc. Fla. State Hort. Soc. 110:36-39.

Owen, J.S. and J.E. Altland. 2008. Container height and douglas fir bark texture affect substrate physical properties. HortScience 43:505-508.

Puustjarvi, V. and R.A. Robertson. 1975. Physical and chemical properties, p. 23-38. In: Peat in horticulture. Academic Press, London, UK.

Spomer, L.A. 1974. Two classroom exercises demonstrating the pattern of container soil water distribution. HortScience 9:152-153.

Van Genuchten, M.T. and D.R. Nielsen. 1985. On describing and predicting the hydraulic properties of unsaturated soils. E.G.S.; Ann. Geophysicae. 3:615-628. 